\title{
In Vitro Regeneration of ICP 8863 Pigeon Pea (Cajanus cajan (L.) Millsp.) Variety using Leaf Petiole and Cotyledonary Node Explants and Assessment of their Genetic Stability by RAPD Analysis
}

\author{
Nirmala Nalluri and Vasavi Rama Karri* \\ Department of Biotechnology, GITAM Institute of Technology, GITAM (Deemed to be University), \\ Visakhapatnam - 530045, Andhra Pradesh, India; nirmala2112@gmail.com, vasavi8@gmail.com
}

\begin{abstract}
Objectives: A reliable in vitro regeneration protocol by direct organogenesis was developed in ICP 8863 variety of pigeon pea using leaf petiole and cotyledonary node explants. Methods: For direct shoot bud induction, leaf petiole explants from seven-day-old in vitro grown seedlings and cotyledonary node explants from twelve-day-old were cultured on MS medium supplemented with various combinations and concentrations of BAP, NAA and Kinetin. Induced shoot buds of both the explants were elongated on MS medium fortified with different concentrations of BAP, NAA and GA The wellelongated shoots of both the explants were transferred to MS medium supplemented with various concentrations of IBA. Finally, the regenerated plants were transferred to soil and vermiculate mixture in 1:1 ratio for acclimatization. Further, molecular characterization of the in vitro regenerated plants was carried out using eight OPP and OPAZ RAPD primer series. Findings: High frequency of shoot bud induction (92\%) was observed in leaf petiole explants with $2.0 \mathrm{mg} / \mathrm{L} 6$-BAP concentration compared to cotyledonary node explants. The induced shoots were kept for elongation and maximum percentage of elongation (93\%) was noticed in leaf petiole explants with $1.0 \mathrm{BAP}+0.1 \mathrm{NAA}+2.0 \mathrm{GA}$ mg/L concentrations compared to cotyledonary node explants. The well-developed shoots of both the explants showed profuse rooting, where high percentage of rooting ( $95 \%$ ) was observed in leaf petiole explants with $0.5 \mathrm{mg} / \mathrm{L} \mathrm{IBA}$ concentration. The pattern of amplification resulted through RAPD analysis confirmed the genetic stability of in vitro regenerated plants. Improvement: The regeneration protocol standardized in this study is suitable and reliable to develop transgenic pigeon pea plants by agrobacterium mediated genetic transformation.
\end{abstract}

Keywords: Auxins, Cytokinins, Gibberellins, Organogenesis, Pigeonpea

\section{Introduction}

Pigeon pea [Cajanus cajan (L.) Millsp.] is one of the most important perennial food legume crops of rain-fed agriculture in the semi-arid tropics, which occupies fifth position in area, compared to the other legume crops like soybean, common bean, peanut and chickpea ${ }^{1}$. India contributes to $90 \%$ of the global production, where it is cultivated in 3.8 million hectares $\frac{2,3}{3}$. Pigeon pea contains $20-22 \%$ of protein and sulphur containing amino acids, like cysteine and methionine ${ }^{4}$, whose content is more than three times in cereals. Because of its high protein content, it is used as an important source of protein in Indians vegetarian diet. In addition, it also contains 3-5 $\%$ of soluble sugar, $1-2 \%$ fats, 3-4 \% crude fiber, $45-55 \%$ starch and 3-4 \% ash ${ }^{5}$.

Mostly, pigeon pea is cultivated as an intercrop with other crops like sorghum (Sorghum bicolor), pearl millet (Pennisetum glaucum), maize (Zea mays) or with other legumes like peanuts (Arachis hypogaea) to maintain soil

*Author for correspondence 
fertility. It is cultivated in various types of soils like black clay to sandy soil and is sensible to waterlogged conditions. The major constraint in its cultivation is sensitivity to various diseases like, Phytophthora stem blight, sterility mosaic virus, Fusarium wilt and insect pests like Helicoverpa armigera, pod fly and storage grain pests, causing major yield loss 6 . Efforts to face these problems through conventional breeding methods were not successful due to limited genetic variation in the cultivated germplasm and incompatibility with wild species ${ }^{\mathrm{T}}$. So, these problems can be addressed by introducing genes conferring disease and insect resistance through genetic engineering strategy ${ }^{8}$.

Standardization of an efficient protocol for in vitro regeneration is necessary to develop transgenic pigeon pea plants with desired characters. As legumes are reported to be recalcitrant to regeneration, it is crucial to standardize a protocol in pigeon pea.

It depends upon various factors like genotype, source of the explant and combination of various plant growth hormones. Previously, various researchers reported regeneration by using different explants in pigeon pea through organogenesis and somatic embryogenesis $\frac{9-14}{}$.

Compared to somatic embryogeneis, regeneration by direct organogenesis was reported as most effective procedure for the development of pigeon pea transgenic plants. Among the various explants used, leaf tissue was used most frequently followed by cotyledon, cotyledonary node, epicotyl, hypocotyl and axillary bud. Type of an explant also plays an important role in regeneration to induce shoot buds. Using leaf explants, regeneration was reported in different pigeon pea varieties like ICPL 161, ICPL 88039 and UPAS $120^{\frac{10,15,16}{1}}$, but these protocols did not show high shoot bud induction through direct regeneration. Thus, there is a need to develop an efficient direct organogenesis protocol, to develop transgenic pigeon pea plants through transformation.

Genetic stability of regenerated plants is another aspect of plant propagation, which is essential for genetic transformation. In tissue culture derived plants, variations are common which may limit the application of in vitro regeneration protocol ${ }^{17}$. Earlier, genetic analysis of in vitro regenerated plants in many species was studied using RAPD $\stackrel{18}{ }$ and ISSR $\stackrel{19}{\underline{9}}$ markers. Earlier, some researchers confirmed genetic stability in pigeon pea plants by RAPD analysis ${ }^{20}$. Genetic variations may occur in in vitro regenerated plants due to various factors like type of explant, genotype, growth regulators, mode of regenera- tion etc ${ }^{21,22}$. So, it is required to check the genetic stability of in vitro regenerated plants of any plant species before proceeding to genetic transformation studies.

In this study, we intend to develop an in vitro regeneration protocol in ICP 8863 variety of pigeon pea using leaf petiole and cotyledonary node explants and to analyze the genetic stability of in vitro regenerated plantlets by RAPD analysis.

\section{Materials and Methods}

\subsection{Plant Material}

Pigeonpea ICP 8863 variety seeds were selected to carry out this experiment. This is a high yielding and medium duration variety, which is suitable for sole cropping and intercropping.

Seeds were procured from plant breeding Department of International Crops Research Institute for the SemiArid Tropics, Patancheru, Telangana, India.

\subsection{Seed Treatment and Germination}

Mature and uniform seeds were taken and were surface sterilized with $70 \%$ ethanol for $1 \mathrm{~min}$ followed by $0.1 \%(\mathrm{w} / \mathrm{v})$ mercuric chloride containing 1-2 drops of Tween-20 for $8 \mathrm{~min}$. Later these seeds were washed with sterile double distilled water for four to five times and were soaked for $14 \mathrm{~h}$ in sterile double distilled water at room temperature. Then the imbibed seeds were inoculated in sterile test tubes containing solid MS medium ${ }^{23}$ containing $0.8 \%$ and $3 \%$ sucrose.

\subsection{In vitro Shoot Regeneration from Leaf petiole and Cotyledonary Node Explants}

Petioles and cotyledonary nodes excised from 7-dayold and 12-day-old aseptically germinated seedlings were used as explants for shoot bud induction. Both the explants were inoculated in culture medium supplemented with various concentrations of cytokinins like 6-Benzylaminopurine (BAP) and Kinetin and auxin like $\alpha$-napthaleneacetic acid (NAA) in different combinations for shoot bud induction (The details of the treatments are given in Table 1). Minimum number of 50 explants was taken for each treatment and was repeated thrice. The explants were sub-cultured for every two weeks on fresh MS basal medium with similar combinations of hormones. Data was recorded for various parameters like 


\begin{tabular}{|c|c|c|c|c|c|c|c|c|c|c|c|c|c|c|c|c|c|c|}
\hline \multirow{4}{*}{ 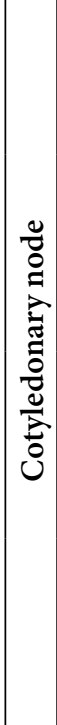 } & 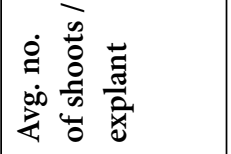 & 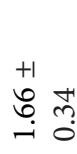 & $\begin{array}{l}\infty \\
\infty \\
1 \\
0 \\
+1 \\
0 \\
i \\
i\end{array}$ & $\stackrel{+1}{\stackrel{n}{n}} \stackrel{\text { m. }}{0}$ & $\begin{array}{ll}+1 & \\
m & \hat{\sigma} \\
& 0\end{array}$ & $\begin{array}{c}\infty \\
\infty \\
0 \\
0 \\
+1 \\
0 \\
i n\end{array}$ & $\begin{array}{l}\infty \\
1 \\
0 \\
0 \\
+1 \\
0 \\
0\end{array}$ & $\begin{array}{ll}+1 \\
\stackrel{+}{m} & \stackrel{m}{n} \\
& 0\end{array}$ & $\begin{array}{c}\infty \\
\infty \\
1 \\
0 \\
+1 \\
0 \\
\infty \\
\infty\end{array}$ & 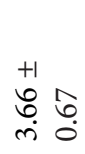 & 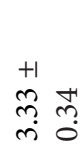 & $\begin{array}{l}0 \\
\dot{1} \\
+1 \\
0 \\
\dot{m}\end{array}$ & $\mid \begin{array}{c}\infty \\
1 \\
1 \\
0 \\
+1 \\
0 \\
0 \\
-1 \\
\end{array}$ & $\begin{array}{l}\infty \\
\infty \\
0 \\
0 \\
+1 \\
0 \\
-1\end{array}$ & $\begin{array}{l}+1 \\
\stackrel{+}{0} \\
\stackrel{0}{0} \\
\dot{r} \\
\dot{0}\end{array}$ & 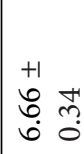 & $\begin{array}{c}\infty \\
1 \\
0 \\
0 \\
+1 \\
0 \\
+ \\
+\end{array}$ & $\begin{array}{ll}+1 & \\
\stackrel{1}{0} & \infty \\
i & 0 \\
i & 0\end{array}$ \\
\hline & 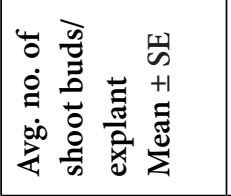 & $\begin{array}{l}\hat{1} \\
0 \\
0 \\
+1 \\
0 \\
0 \\
\dot{r} \\
\dot{r}\end{array}$ & $\begin{array}{c}\infty \\
1 \\
0 \\
+1 \\
+1 \\
0 \\
\dot{n}\end{array}$ & $\begin{array}{l}\hat{0} \\
0 \\
+1 \\
+ \\
0 \\
\dot{+} \\
+\end{array}$ & $\mid \begin{array}{c}\infty \\
10 \\
0 \\
+1 \\
+1 \\
0 \\
0 \\
0\end{array}$ & $\begin{array}{l}0 \\
\infty \\
\dot{0} \\
+1 \\
0 \\
0 \\
\infty \\
\infty\end{array}$ & 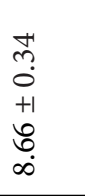 & $\begin{array}{l}\ddot{+} \\
m \\
0 \\
+1 \\
\infty \\
\tilde{o} \\
0 \\
=\end{array}$ & $\begin{array}{l}\hat{0} \\
\dot{0} \\
+1 \\
\hat{n} \\
= \\
=\end{array}$ & $\begin{array}{l}\infty \\
1 \\
0 \\
+1 \\
+1 \\
0 \\
\\
\end{array}$ & $\begin{array}{l}0 \\
0 \\
0 \\
+1 \\
0 \\
0 \\
0 \\
0\end{array}$ & $\begin{array}{l}\hat{0} \\
\dot{0} \\
+1 \\
m \\
\tilde{\sigma} \\
0\end{array}$ & $\begin{array}{c}\infty \\
0 \\
1 \\
0 \\
+1 \\
0 \\
0 \\
r \\
\end{array}$ & $\begin{array}{l}\ddot{+} \\
\tilde{o} \\
+1 \\
m \\
m \\
m\end{array}$ & $\begin{array}{l}\infty \\
\infty \\
0 \\
+1 \\
m \\
m \\
i n\end{array}$ & $\begin{array}{l}1 \\
0 \\
0 \\
+1 \\
0 \\
0 \\
0 \\
0\end{array}$ & $\begin{array}{l}0 \\
0 \\
0 \\
+1 \\
+1 \\
0 \\
0 \\
1 \\
\end{array}$ & $\begin{array}{l}\infty \\
10 \\
0 \\
+1 \\
0 \\
0 \\
0\end{array}$ \\
\hline & 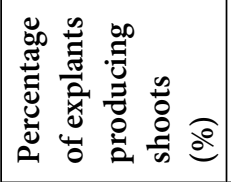 & $\stackrel{\infty}{m}$ & $\mathcal{F}$ & 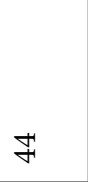 & ర & $\widetilde{\sigma}$ & $\stackrel{\infty}{\circ}$ & 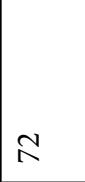 & $\stackrel{゚}{\wedge}$ & in & in & in & $\stackrel{\sharp}{\sim}$ & b & $\stackrel{\infty}{+}$ & $R$ & 8 & in \\
\hline & 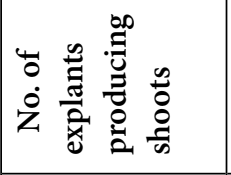 & 2 & $\vec{\nabla}$ & $\widetilde{\sim}$ & $m$ & $\vec{m}$ & m゙ & 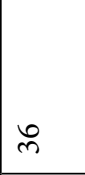 & $\stackrel{\infty}{m}$ & $\stackrel{\infty}{\sim}$ & $\hat{\imath}$ & i & $\approx$ & $\stackrel{\infty}{\sim}$ & $\stackrel{H}{N}$ & $\stackrel{m}{m}$ & in & $\stackrel{\llcorner}{\sim}$ \\
\hline \multirow{4}{*}{ 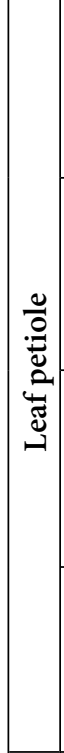 } & 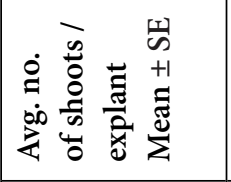 & 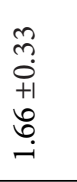 & $\begin{array}{l}\ddot{+} \\
m \\
0 \\
+1 \\
m \\
m \\
-1\end{array}$ & $\begin{array}{l}m \\
0 \\
0 \\
+1 \\
+1 \\
0 \\
i \\
i\end{array}$ & 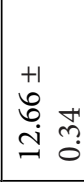 & $\begin{array}{c}\hat{0} \\
0 \\
0 \\
+1 \\
m \\
m \\
+ \\
\end{array}$ & $\begin{array}{l}\ddot{+} \\
0 \\
0 \\
+1 \\
+1 \\
0 \\
\dot{0} \\
\text { in }\end{array}$ & 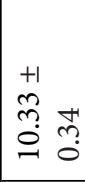 & $\begin{array}{l}+ \\
m \\
0 \\
+1 \\
+1 \\
0 \\
0 \\
0\end{array}$ & $\begin{array}{l}8 \\
0 \\
0 \\
+1 \\
8 \\
0 \\
0\end{array}$ & $\begin{array}{l}8 \\
8 \\
0 \\
+1 \\
0 \\
0 \\
0 \\
0\end{array}$ & $\begin{array}{l}\infty \\
\infty \\
0 \\
0 \\
+1 \\
m \\
0 \\
0\end{array}$ & $\begin{array}{c}\dot{1} \\
\tilde{n} \\
0 \\
+1 \\
+1 \\
0 \\
\dot{0} \\
\dot{n} \\
\end{array}$ & $\begin{array}{l}1 \\
0 \\
0 \\
+1 \\
+1 \\
0 \\
0 \\
1 \\
\end{array}$ & $\begin{array}{l}\hat{n} \\
0 \\
+1 \\
0 \\
0 \\
+\end{array}$ & $\begin{array}{l}1 \\
\hat{n} \\
0 \\
+1 \\
0 \\
i n \\
\end{array}$ & $\begin{array}{c}+ \\
m \\
0 \\
+1 \\
+1 \\
\vdots \\
0 \\
- \\
\end{array}$ & $\begin{array}{l}\infty \\
1 \\
0 \\
+1 \\
+1 \\
0 \\
-1\end{array}$ \\
\hline & 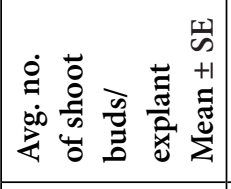 & $\begin{array}{l}\ddot{+} \\
m \\
0 \\
+1 \\
0 \\
0 \\
\dot{n} \\
\dot{n}\end{array}$ & $\begin{array}{l}2 \\
\infty \\
0 \\
+1 \\
0 \\
0 \\
+ \\
+ \\
\end{array}$ & $\begin{array}{l}m \\
\tilde{o} \\
0 \\
+1 \\
\infty \\
\tilde{b} \\
\tilde{b}\end{array}$ & 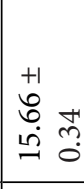 & $\begin{array}{c}\hat{0} \\
0 \\
0 \\
+1 \\
\tilde{m} \\
a \\
\end{array}$ & 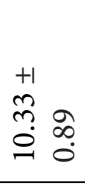 & $\begin{array}{l}+1 \\
m \\
m \\
m \\
n\end{array}$ & $\begin{array}{l}\ddot{+} \\
m \\
0 \\
+1 \\
m \\
m \\
i\end{array}$ & $\begin{array}{l}\hat{\sigma} \\
\dot{0} \\
+1 \\
m \\
m \\
-1\end{array}$ & $\begin{array}{c}\infty \\
0 \\
0 \\
0 \\
+1 \\
0 \\
0 \\
-1\end{array}$ & 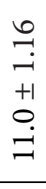 & $\begin{array}{l}+1 \\
1 \\
0 \\
+1 \\
0 \\
0 \\
0 \\
0 \\
\end{array}$ & 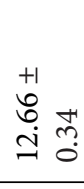 & $\mid \begin{array}{l}3 \\
m \\
0 \\
+1 \\
0 \\
0 \\
0 \\
\infty\end{array}$ & $\mid \begin{array}{l}\infty \\
10 \\
0 \\
0 \\
+1 \\
0 \\
0 \\
0\end{array}$ & $\begin{array}{c}\infty \\
1 \\
0 \\
0 \\
+1 \\
0 \\
+ \\
+ \\
\end{array}$ & $\begin{array}{l}+1 \\
0 \\
+1 \\
6 \\
\dot{n} \\
\dot{n}\end{array}$ \\
\hline & 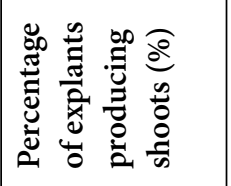 & $\stackrel{i}{*}$ & $\approx$ & 우 & $\sigma$ & กี & $R$ & $\infty$ & 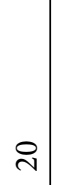 & $\stackrel{\bullet}{\circ}$ & $\stackrel{ }{-}$ & 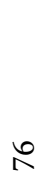 & 8 & $\infty$ & in & t' & ஜे & $\stackrel{\sim}{\sim}$ \\
\hline & 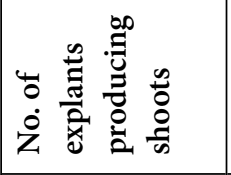 & $\stackrel{m}{=}$ & $\because$ & $\stackrel{i}{ }$ & $\stackrel{8}{7}$ & $\stackrel{\sim}{\sim}$ & $\stackrel{n}{m}$ & F & $\stackrel{0}{-1}$ & $\stackrel{\infty}{\circ}$ & $\stackrel{2}{0}$ & $\stackrel{\infty}{m}$ & $\dot{m}$ & 우 & $\stackrel{\sim}{\sim}$ & กै & 10 & $\simeq$ \\
\hline & 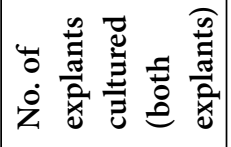 & in & in & in & in & in & in & in & in & in & in & in & in & in & in & in & in & in \\
\hline & 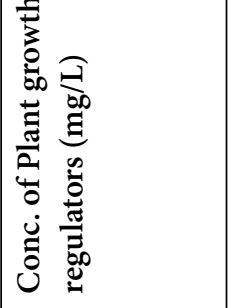 & 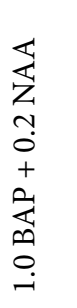 & $\begin{array}{l}\mathbb{3} \\
z \\
z \\
0 \\
+ \\
+ \\
0 \\
0 \\
0 \\
0 \\
-i\end{array}$ & 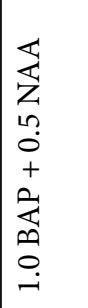 & 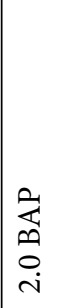 & 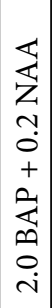 & 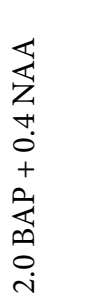 & 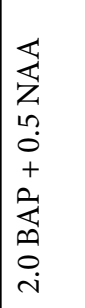 & 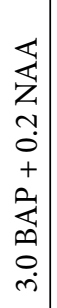 & $\begin{array}{l}\mathbb{3} \\
z \\
+ \\
0 \\
+ \\
+ \\
0 \\
0 \\
0 \\
0 \\
\dot{m}\end{array}$ & 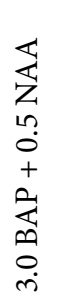 & 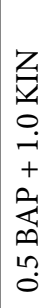 & 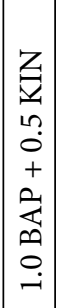 & 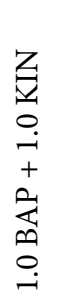 & 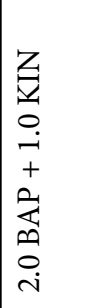 & $\begin{array}{l}Z \\
\text { 量 } \\
\text { o } \\
\text { in }\end{array}$ & 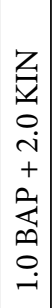 & 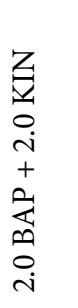 \\
\hline
\end{tabular}




\begin{tabular}{|c|c|c|c|c|c|c|c|c|}
\hline & 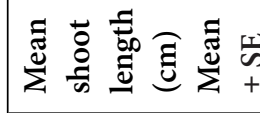 & 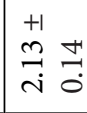 & 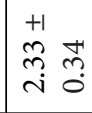 & 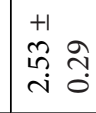 & $\begin{array}{ll}+1 \\
+1 \\
\infty \\
\infty \\
i \\
i\end{array}$ & 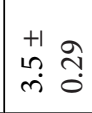 & 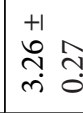 & $\begin{array}{l}+1 \\
\text { } \\
i \\
i\end{array}$ \\
\hline 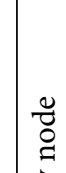 & 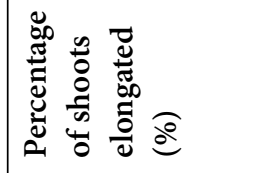 & in & 8 & tే & $\stackrel{n}{n}$ & $\underset{\infty}{+\infty}$ & $N$ & t' \\
\hline $\begin{array}{l}0 \\
\frac{0}{0} \\
\frac{0}{2} \\
0 \\
0\end{array}$ & 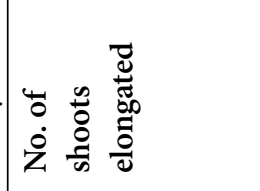 & $\stackrel{2}{\sim}$ & $\stackrel{\infty}{\sim}$ & ते & $\stackrel{\leftrightarrow}{i}$ & $\approx$ & i & $\approx$ \\
\hline & 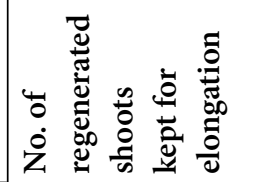 & $\hat{\lambda}$ & p & $\vec{m}$ & $m$ & $\infty$ & in & $\ddot{m}$ \\
\hline & 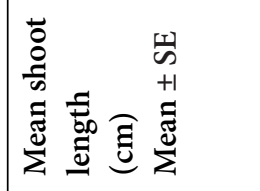 & 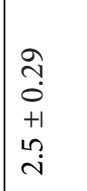 & $\begin{array}{l}\hat{1} \\
0 \\
+1 \\
\infty \\
\infty \\
i \\
i\end{array}$ & 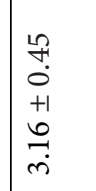 & $\begin{array}{l}+ \\
m \\
0 \\
0 \\
+1 \\
\infty \\
\infty \\
\infty\end{array}$ & \begin{tabular}{|l}
4 \\
0 \\
0 \\
+1 \\
0 \\
0 \\
0 \\
$ن$
\end{tabular} & $\begin{array}{l}1 \\
0 \\
0 \\
+1 \\
\infty \\
\infty \\
\infty \\
0\end{array}$ & $\begin{array}{l}8 \\
0 \\
0 \\
+1 \\
0 \\
\dot{m}\end{array}$ \\
\hline 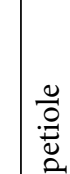 & 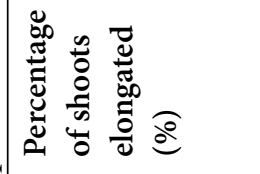 & F & in & in & $\pi$ & 10 & $a$ & 8 \\
\hline త్త్తు & 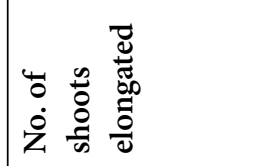 & 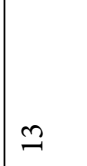 & 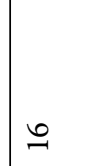 & ì & À & ते & F & $\stackrel{\infty}{\sim}$ \\
\hline & 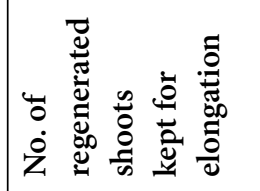 & in & $\tilde{m}$ & $\stackrel{m}{m}$ & $\underset{\infty}{\infty}$ & q & f & F \\
\hline & 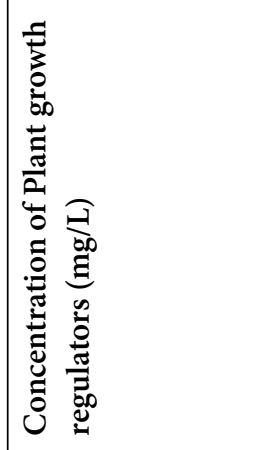 & 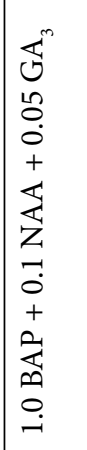 & 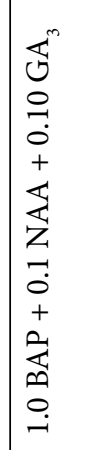 & 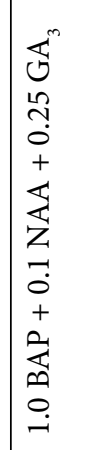 & 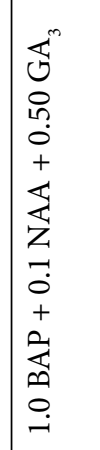 & 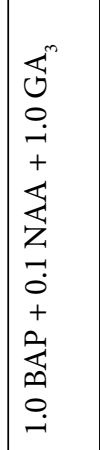 & 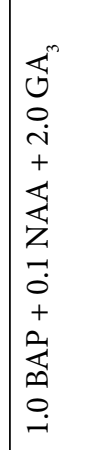 & 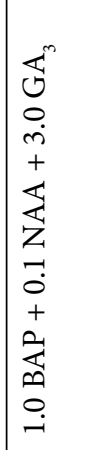 \\
\hline
\end{tabular}

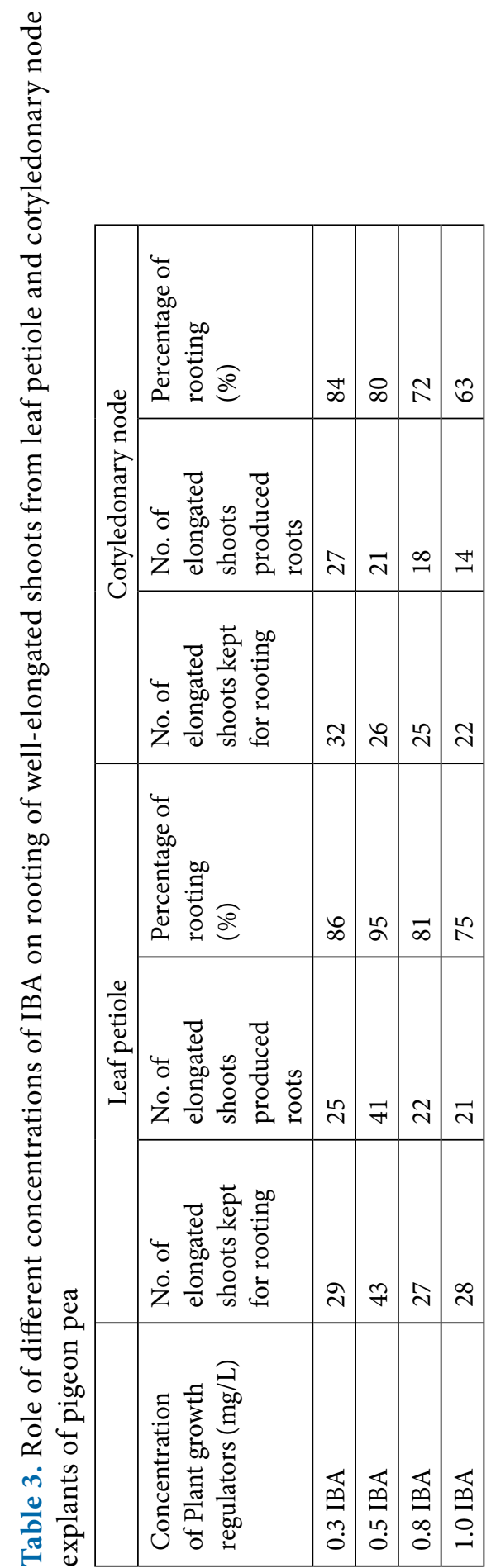


number of explants responded and number of shoot buds per explant for interpretation of results.

\subsection{In vitro Shoot Elongation}

After four weeks, well-developed shoots regenerated from both leaf petiole and cotyledonary node explants were separated from the shoot clumps and were inoculated on the shoot elongation medium containing $1.0 \mathrm{mg} / \mathrm{L} \mathrm{BAP}$, $0.1 \mathrm{mg} / \mathrm{L}$ NAA and various concentrations of Gibberellic Acid $\left(\mathrm{GA}_{3}\right)(0.05,0.10,0.25,0.50,1.0,2.0,3.0 \mathrm{mg} / \mathrm{L}$ ) (see Table 2). For every two weeks, they were sub-cultured on fresh MS medium with similar hormonal combination and the number of well-elongated shoots was counted regularly.

\subsection{In vitro Root Induction and Acclimatization of Plantlets}

The well elongated shoots of both the explants were transferred to the root induction medium containing MS medium fortified with various concentrations of Indole-3-butyric Acid (IBA) (0.3, 0.5, 0.8 and $1.0 \mathrm{mg} / \mathrm{L}$ ). After two to three weeks, the rooted plants with welldifferentiated leaves were carefully removed from the test tubes and were gently washed with double distilled water to remove agar from the roots. Then the plantlets were transferred to small plastic glasses containing autoclaved soil and soilrite in 1:1 ratio and were initially hardened in culture room at controlled conditions. After two weeks of hardening, they were transferred finally to small pots for acclimatization in green house.

\subsection{Genomic DNA Extraction and Genetic Stability Analysis of Acclimatized Plants by using RAPDs}

The genetic stability analysis of in vitro regenerated acclimatized plants was carried out using eight RAPD primers from the OPP and OPAZ series (Operon Technologies, Alameda, USA). Genomic DNA was isolated using CTAB method ${ }^{25}$ from six randomly selected regenerated plants from both the explants (three plants of each explant). Briefly, $2 \mathrm{gm}$ of fresh leaves were grinded to achieve a fine powder using liquid nitrogen and were centrifuged by adding $5 \mathrm{ml}$ of extraction buffer ( $2 \%$ CTAB, $20 \mathrm{mM}$ EDTA, $2 \%$ PVP) $1.4 \mathrm{M} \mathrm{NaCl}, 100 \mathrm{mM}$ Tris-HCL pH 8.0 and $1 \% \beta$-mercaptoethanol) and were incubated at $65^{\circ} \mathrm{C}$ for $1 \mathrm{~h}$. The collected supernatant was treated with RNase enzyme $(100 \mu \mathrm{g} / \mathrm{mL})$ and incubated at $37^{\circ} \mathrm{C}$ for $30 \mathrm{~min}$ and was extracted twice with chloroform and isoamylalcohol $(24: 1 \mathrm{v} / \mathrm{v})$. Afterwards, the DNA was precipitated with ice-cold isopropanol and washed 2-3 times with 70 $\%$ ethanol. The DNA pellet was air-dried and eluted with $1 \mathrm{X}$ TE buffer $(100 \mu \mathrm{l})$ and stored at $-20^{\circ} \mathrm{C}$. The qualitative and quantitative analysis of DNA was assessed by spectrophotometer and agarose gel electrophoresis. A total of 8 RAPD primers (Operon Technologies Almeda, USA) were used for RAPD analysis.

Total $20 \mu \mathrm{L}$ of PCR reaction mix was prepared with 2.0 $\mu \mathrm{L}$ of 10x PCR buffer with $15 \mathrm{mM}$ magnesium chloride, $0.5 \mu \mathrm{L}$ of $10 \mathrm{mM}$ dNTPs, $1 \mu \mathrm{L}$ forward primer, $1 \mu \mathrm{L}$ reverse primer, $2 \mu \mathrm{L}$ of genomic DNA, $0.3 \mu \mathrm{L}$ of Taq polymerase and sterile milli-Q water. PCR amplification was carried out in a Veriti thermal cycler (Applied Biosystems, USA). The conditions for PCR amplification are as follows: Initial denaturation at $94^{\circ} \mathrm{C}$ for $3 \mathrm{~min}$ followed by 45 cycles at $94^{\circ}$ $\mathrm{C}$ for $1 \mathrm{~min}$, annealing at $37^{\circ} \mathrm{C}$ for $1 \mathrm{~min}$, initial extension at $72^{\circ} \mathrm{C}$ for $2 \mathrm{~min}$ followed by final extension at $72^{\circ} \mathrm{C}$ for 7 min. The amplified products were resolved on $1.5 \%$ agarose gel and the DNA band sizes were determined by using $1 \mathrm{~kb}$ DNA ladder (Promega, USA).

\section{Results and Discussion}

The percentage of germination was high (70-80 \%) in surface sterilized seeds cultured on MS basal medium (Figure 1 (a) and (b)) compared to sterile wet filter papers (30-40\%). In this experiment, we have selected leaf petiole and cotyledonary node explants, as they are more reproducible and potent to carryout genetic transformation studies. For an efficient shoot bud induction, age of an explant, type of an explant and plant growth hormonal combination plays an important role. In our study, leaf petiole and cotyledonary node explants collected from seven day old and twelve day old in vitro germinated seedlings showed high percentage of shoot bud induction and no shoot bud induction was noticed on plain MS medium without any plant growth regulators. Previously in pigeon pea, in vitro regeneration was reported from various explants like, cotyledonary node $\frac{11,13,25-28}{}$, leaves $\frac{10,11,13,15,29}{}$, epicotyl ${ }^{14}$, shoot apices $^{\frac{12}{2}}$, leaf petiole $\frac{10,30,31}{}$, leaf and apical meristem ${ }^{32}$ and auxiliary buds ${ }^{33}$. For direct shoot bud induction using leaf petiole and cotyledonary node explants, various combinations of growth hormones like BAP, NAA and Kinetin were used in different concentrations. In case of leaf petiole explant, increase in size of the leaf lamina and bulging 
at the petiolar end of the leaf was observed in the first week of inoculation (Figure 1c) and after one week, shoot bud induction was initiated from the bulged part of the leaf petiole (Figure 1d).

Among the various combinations and concentrations of BAP, kinetin and NAA tested, MS basal medium fortified with $2.0 \mathrm{mg} / \mathrm{L}$ BAP concentration showed highest shoot bud induction (92\%) in leaf petiole explants (Table 1). These results are in correlation to the earlier reports of $\mathrm{fl}^{13}$ and ${ }^{34}$, where high shoot bud regeneration was observed at $2.0 \mathrm{mg} / \mathrm{L}$ BAP concentration using cotyledonary node explants and based on these studies, BAP was noticed to be a potent growth hormone to increase the shoot bud

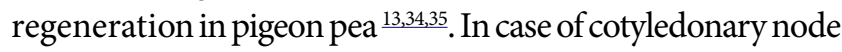
explants, maximum shoot induction percentage $(76 \%)$ was observed on MS basal medium supplemented with $3.0 \mathrm{mg} / \mathrm{L}$ $\mathrm{BAP}+0.2 \mathrm{mg} / \mathrm{L}$ NAA concentrations. Recently ${ }^{\frac{36}{6}}$ reported direct shoot bud regeneration in ICPL 87 pigeon pea variety at $2.0 \mathrm{mg} / \mathrm{L} \mathrm{BAP}+0.5 \mathrm{mg} / \mathrm{L}$ NAA concentrations. Like wise, $\frac{26}{6}$ and ${ }^{37}$ reported that multiple shoot regeneration of legumes was possible at low concentrations of auxins and reported that higher concentrations of NAA reduces the shoot bud regeneration frequency. Few researchers reported, direct shoot regeneration from the cotyledonary surface at higher concentrations of $\mathrm{BAP}^{38}$. But, in our experiment use of high concentrations of BAP resulted in callus formation, which was similar to the results reported by ${ }^{30}$, where callus formation was observed in leaf petiole explants cultured with high concentrations of BAP and NAA. $\stackrel{16}{2}$ also reported shoot regeneration using leaf petiole explants on MS medium supplemented with equal concentrations of BAP and Kinetin, but the percentage of regeneration was less ( $46 \%$ ) compared to our results. ${ }^{39}$ developed an indirect regeneration protocol in ICP 8863 pigeon pea variety using leaf and epicotyl explants with an intervening callus stage. However, this protocol may have chances of developing phenotypic variations within the same culture and results in genetic instability of the regenerated plants. But, the direct regeneration protocol standardized in the current study enables regeneration through direct shoot organogenesis without any intervening callus stage. There were also some earlier reports on indirect regeneration using leaf explants, but the reported percentage of shoot bud induction was low $(36 \%)^{40}$. Even though,,$^{41}$ reported $81 \%$ of shoot bud induction from cotyledonary explants, the percentage of conversion of shoot buds to fully developed shoots was low.
In vitro regeneration is also reported from leaf explants and apical meristem with attached leaf, where callus formation was noticed in leaf explants using Thidiazuron (TDZ) and the percentage of shoot induction was only $77.8 \%{ }^{32}$. Based on the studies on whole plant regeneration from axillary buds in different varieties of pigeon pea, $\frac{33}{}$ stated that regeneration frequency varies among different varieties and the same was earlier reported by other researchers $\frac{13,15,27,41,42-45}{1}$. The induced shoots of both the explants were kept for elongation on MS medium containing various concentrations of BAP, NAA and GA . According to the previous studies, elongation of induced shoots depends on various factors like substitution of plant growth regulators ${ }^{46,47}$ to alter the medium ${ }^{25,48}$ and change in light conditions. For better elongation of the proliferated shoots, the concentration of BAP was reduced to half of the concentration used for shoot induction and the medium was additionally supplemented with NAA and $\mathrm{GA}_{3}$. Our results are in correlation with the studies of $^{37}$ who also reported that use of high concentrations of BAP results in low frequency of shoot elongation. Within two weeks of subculture, the shoots were elongated up to $4 \mathrm{~cm}$ and high percentage of shoot elongation (93\%) was noticed in leaf petiole explants cultured on MS medium supplemented with $1.0 \mathrm{mg} / \mathrm{L} \mathrm{BAP}+0.1 \mathrm{mg} / \mathrm{L} \mathrm{NAA}+2.0$ $\mathrm{mg} / \mathrm{L} \mathrm{GA}_{3}$ concentrations (Figure 1 (e) and (f)) (Table 2). In the case of cotyledonary node explants, maximum percentage of elongation was observed with $1.0 \mathrm{mg} / \mathrm{L}$ 6-BAP $+0.1 \mathrm{mg} / \mathrm{L} \mathrm{NAA}+1.0 \mathrm{mg} / \mathrm{L} \mathrm{GA}_{3}$ concentrations (84 \%). According to ${ }^{14}$, no elongation was observed when the MS medium was supplemented with only BAP or BAP in combination with IAA without $\mathrm{GA}_{3}$.

Finally, the well-elongated shoots of both the explants were transferred to root induction medium containing various concentrations of IBA. Within two weeks of sub-culture, adventitious roots were initiated and the percentage of rooting was high (95\%) in shoots obtained from leaf petiole explants cultured on $0.5 \mathrm{mg} / \mathrm{L}$ IBA compared to cotyledonary node explants (Figure $1(\mathrm{~g})(\mathrm{h})$ ), where only $84 \%$ of rooting was observed with $0.3 \mathrm{mg} / \mathrm{L}$ IBA concentration (Table 3). Based on this study, we report that in both the explants, lower concentrations of IBA supported better root proliferation compared to high concentrations.

Our results are in support to the earlier reports of $\frac{27,25,49}{2}$ and some other researchers, who also reported that the addition of NAA and IBA resulted in $80-85 \%$ of rooting 15 . These profusely rooted regenerated plantlets were 
transferred to small pots containing autoclaved soil and soilrite mixture in 1:1 ratio and were initially hardened in culture room (Figure 2a) and were finally transferred to green house for acclimatization (Figure 2b). Morphologically the regenerated plants showed normal growth with well-developed leaves. Out of eight RAPD primers from the OPP and OPAZ series tested (Table 4), two primers produced better amplification and resulted in five bands ranging from 520-4000 bp with OPP09 marker (Figure 3) and five bands ranging from 300-2200 bp with OPAZ18 marker (Figure 4) respectively with regenerated plants. The amplification pattern of the in vitro regenerated plants was similar to the donor plants of the explants and no apparent phenotypic variations were observed, which confirms their genetic stability. To our knowledge this is the first report of in vitro regeneration of ICP 8863 pigeon pea variety through direct organogenesis using leaf petiole and cotyledonary node explants and is suitable for further genetic transformation studies.

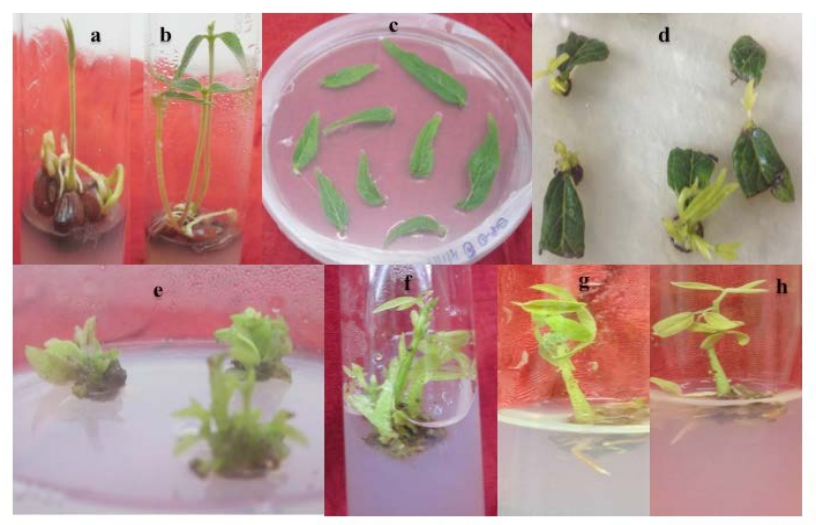

Figure 1. Regeneration of multiple shoots from leaf petiole explants obtained from in vitro germinated pigeon pea seedlings. (a) Two day old germinated seedlings on basal MS medium, (b) Six day old germinated seedlings on basal MS medium, (c) Seven day old leaf petiole explants inoculated on shoot induction medium, (d) Induction of multiple shoot buds from the leaf petiolar region inoculated on MS medium fortified with $2.0 \mathrm{mg} / \mathrm{l} 6-\mathrm{BAP},(\mathrm{e}, \mathrm{f})$ Multiple shoot elongation of proliferated shoots on MS medium containing $1.0 \mathrm{mg} / \mathrm{l}$ BAP, $0.1 \mathrm{mg} / \mathrm{l} \mathrm{NAA}$ and $2 \mathrm{mg} / \mathrm{l} \mathrm{GA} 3$ and $(\mathrm{g}$, h) Rooting of in vitro raised shoots on MS medium supplemented with 1.0 $\mathrm{mg} / \mathrm{l}$ IBA.
Table 4. RAPD primers tested for genetic stability analysis of the acclimatized in vitro regenerated plants from leaf petiole and cotyledonary node explants of ICP 8863 pigeon pea variety

\begin{tabular}{|l|l|}
\hline Primer & Primer sequence (5'-3') \\
\hline OPP-06 & GTGGGCTGAC \\
\hline OPP-07 & GTCCATGCCA \\
\hline OPP-08 & ACATCGCCCA \\
\hline OPP-09 & GTGGTCCGCA \\
\hline OPAZ-16 & AGGCGAACTG \\
\hline OPAZ-17 & CACGCAGATG \\
\hline OPAZ-18 & CCGACGTTGA \\
\hline OPAZ-19 & ACACTCTCGG \\
\hline
\end{tabular}

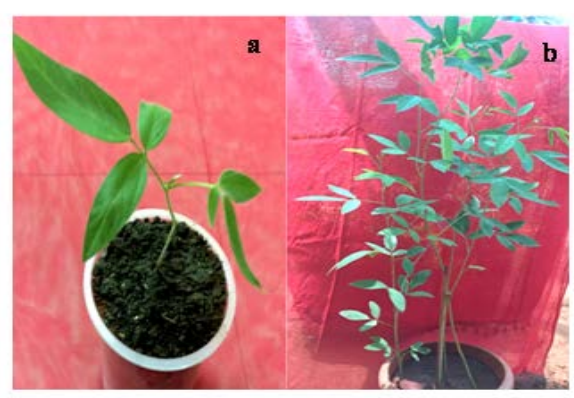

Figure 2. Hardening of in vitro regenerated pigeon pea plantlets, (a) Acclimatization of well-rooted plants in 1:1 ratio of soil and soilrite mixture (b) Hardened plant in green house.

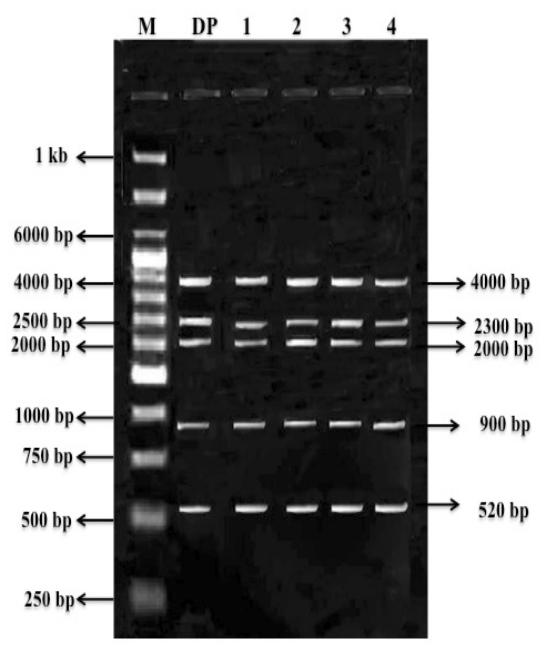

Figure 3. Genetic stability analysis of in vitro regenerated plants from leaf petiole explants using OPP09 RAPD primer. M-1kb DNA ladder, DP-Donar Plant, Lanes 1-4 in vitro regenerated plants. 


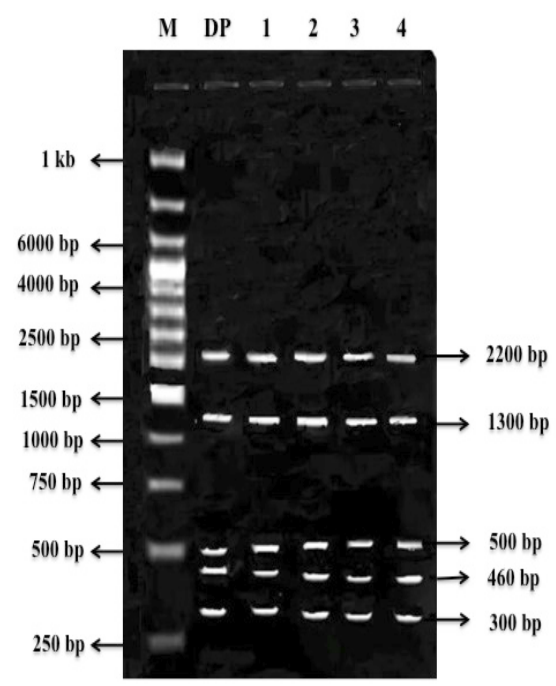

Figure 4. Genetic stability analysis of in vitro regenerated plants from cotyledonary node explants using OPAZ18 RAPD primer. M-1kb DNA ladder, DP - Donar Plant, Lanes 1-4 in vitro regenerated plant.

\section{Conclusion}

In the present study, an efficient and reliable protocol through direct organogenesis was developed for in vitro regeneration of ICP 8863 variety of pigeon pea using leaf petiole and cotyledonary node explants, which can be used to develop transgenic pigeon pea plants by agrobacterium mediated transformation.

\section{Acknowledgements}

The authors are grateful to SERB-YSS (SB/YS/LS-83/2014 to Dr. K. Vasavi Rama) for their encouragement and financial support to this project. The authors are thankful to Prof. P. B. Kirti, Department of Plant Sciences, University of Hyderabad for his continuous guidance and valuable support to complete this work. The authors also acknowledge Dr. C. V. Sameer Kumar, Senior Scientist, ICRISAT, India and authorities of ICRISAT for providing seed material to carryout the study. We are thankful to Prof. Ch. Ramakrishna, Director, UGC Affairs and Research Activities, GITAM (Deemed to be University), for his support to carry out this project.
We are thankful to Department of Biotechnology, G. I. T., GITAM (Deemed to be University), Visakhapatnam for their support.

\section{References}

1. Tissue culture approaches to pigeon pea improvement. 1997. http://oar.icrisat.org/4453/

2. Food and Agriculture Data. 2013. http://www.fao.org/faostat/en/\#home

3. Srivastava SK, Sivaramane N, Mathur VC. Diagnosis of pulses performance of India. Agricultural Economics Research Review. 2010. p. 1-12.

4. Pigeon pea: Nutrition and products. 1990. https://eurekamag.com/pdf/003/003884990.pdf

5. Pigeon pea: Physiology of yield formation. 1990. https:// www.cabdirect.org/cabdirect/abstract/19910742880

6. Parekh M, Mahatma M, Kapadia C. In vitro regeneration of pigeon pea [Cajanus cajan (L.) Millsp.] genotype GT-102 using apical meristem. Journal of Cell and Tissue Research. 2014; 14(1):4099-103.

7. Pigeon pea: Geography and importance. 1990. https:// www.cabdirect.org/cabdict/abstract/19910742877

8. Transgenic approaches to crop improvement. 2000. https:// academic.oup.com/jxb/article/51/suppl_1/487/502357

9. Singh ND, Sahoo L, Saini R, Sarin NB, Jaiwal PK. In vitro regeneration and recovery of primary transformants from shoot apices of pigeon pea using Agrobacterium tumefaciens. Physiology and Molecular Biology of Plants. 2004; 10(1):65-74.

10. Dayal S, Lavanya M, Devi P, Sharma KK. An efficient protocol for shoot regeneration and genetic transformation of pigeon pea (Cajanus cajan [L.] Millsp.) using leaf explants. Plant Cell Reports. 2003; 21(11):1072-9. PMid: 12836001. https://doi.org/10.1007/s00299-003-0620-y

11. Singh ND, Sahoo L, Jaiwal PK. In vitro shoot organogenesis and plant regeneration from cotyledonary node and leaf explants of pigeon pea (Cajanus cajan L. Millsp.). Physiology and Molecular Biology of Plants. 2002; 8(1):133-40.

12. Geetha N, Venkatachalam P, Lakshmi Sita G. Agrobacterium-mediated genetic transformation of pigeon pea (Cajanus cajan L.) and development of transgenic plants via direct organogenesis. Plant Biotechnology. 1999; 16(3):213-8. https://doi.org/10.5511/plantbiotechnology.16.213

13. Geetha N, Venkatachalam P, Prakash V, Lakshmi Sita G. High frequency induction of multiple shoots and plant regeneration from seedling explants of pigeon pea (Cajanus cajan L.). Current Science. 1999; 75(10):1036-41. 
14. George L, Eapen S. Organogenesis and embryogenesis from diverse explants in pigeon pea (Cajanus cajan L.). Plant Cell Reports. 1994; 13(7):417-20. PMid: 24193914. https://doi.org/10.1007/BF00234150

15. Eapen S, Tivarekar S, George L. Thidiazuron-induced shoot regeneration in pigeon pea (Cajanus cajan L.). Plant Cell, Tissue and Organ Culture. 1998; 53(3):217-20. https://doi.org/10.1023/A:1006060318752

16. Villiers SD, Emongor Q, Njeri R, Gwata E, Hoisington D, Njagi et al. Evaluation of the shoot regeneration response in tissue culture of pigeon pea (Cajanus cajan (L.) Millsp.) varieties adapted to Eastern and Southern Africa. African Journal of Biotechnology. 2008; 7:587-90.

17. Salvi ND, Singh H, Tivarekar S, Eapen S. Plant regeneration from different explants of neem. Plant Cell, Tissue and Organ Culture. 2001; 65(2):159-62. https://doi. org/10.1023/A:1010672809141

18. Williams JGK, Kuubelik AR, Livak KJ, Rafalski JA, Tingey SV. DNA polymorphisms amplified by arbitrary primers are useful as geneticmarkers. Nucleic Acids Res. 1990; 18(22):6531-5. PMid: 1979162 PMCid: PMC332606. https://doi.org/10.1093/nar/18.22.6531

19. Zietkiewicz E, Rafalski A, Labuda D. Genome fingerprinting by Simple Sequence Repeat (SSR)-anchored polymerase chain reaction amplification. Genomics. 1994; 20(2):17693. PMid: 8020964. https://doi.org/10.1006/geno.1994.1151

20. Banala M, Marka R, Pamulaparthi A, Nanna RS. In vitro direct regeneration through cotyledon culture in pigeon pea [Cajanus Cajan (L.) Millsp.] and evaluation of genetic fidelity using RAPD markers. International Journal of Plant Research. 2016; 30(1):1-4.

21. Yoshihara G, Saiki H. Iron accumulation in tobacco plants expressing soyabean in the seeds. Transgenic Res. 1998; 7(3):173-80. https://doi.org/10.1023/A:1008836812714

22. Martins M, Sarmento D, Oliveira MM. Genetic stability of micropropagated almond plantlets, as assessed by RAPD and ISSR markers. Plant Cell Reports. 2004; 23(7):492-6. PMid: 15372197. https://doi.org/10.1007/s00299-0040870-3

23. A revised medium for rapid growth and bioassays with tobacco tissue cultures. 1962. https://onlinelibrary.wiley. com/doi/10.1111/j.1399-3054.1962.tb08052.x

24. Murray MG, Thompson WF. Rapid isolation of high molecular weight plant DNA. Nucleic Acids Research. 1980; 8(19):4321-5. PMid: 7433111 PMCid: PMC324241. https://doi.org/10.1093/nar/8.19.4321

25. Shiva Prakash N, Pental D, Bhalla-Sarin N. Regeneration of pigeon pea (Cajanus cajan) from cotyledonary node via multiple shoot formation. Plant Cell Reports. 1994; 13(11):623-7. PMid: 24196241. https://doi.org/10.1007/ BF00232933
26. Franklin G, Jeyachandran R, Melchias G, Ignacimuthu S. Multiple shoot induction and regeneration of pigeon pea (Cajanus cajan (L.) Millsp.) cv. Vamban: From apical and axillary meristem. Current Science. 1998; 74(11):936-7.

27. Mohan ML, Krishnamurthy KV. Plant regeneration in pigeon pea (Cajanus cajan (L.) Millsp.) by organogenesis. Plant Cell Reports. 1998; 17(9):705-10. PMid: 30736530. https://doi.org/10.1007/s002990050469

28. Kaur A, Devi R, Dev A. Efficient in vitro regeneration in pigeon pea from cotyledonary node explants. Journal of Cell and Tissue Research. 2012; 12(1):3075-80.

29. Eapen S, George L. Plant regeneration from leaf discs of peanut and pigeon pea: Influence of benzyladenine, indole acetic acid and indoleacetic acid-amino acid conjugates. Plant Cell, Tissue and Organ Culture. 1993; 35(3):223-7. https://doi.org/10.1007/BF00037274

30. Srinivasan T, Verma VK, Kirti PB. Efficient shoot regeneration in pigeon pea, Cajanus cajan (L) Millisp. using seedling petioles. Current Science. 2004; 86(1):30-2.

31. Priyanka Gawali M, Amrapali A, Akhare, Gahukar SJ. In vitro regeneration of pigeon pea from leaf with petiole explant. Asian Sciences. 2010; 5(1):34-8.

32. Bhausaheb D, Pawar, Ashok S, Jadhav, Sharad V, Pawar, et al. An efficient regeneration system for pigeon pea (Cajanus cajan L.). Journal of Crop Improvement. 2014; 28(6):825-33. https://doi.org/10.1080/15427528.2014.948106

33. Vijay Kumar S, Lokesha R, Janagoudar BS, Muniswamy S. An efficient protocol for whole plant regeneration via auxiliary bud explants and molecular confirmation of pigeon pea [Cajanus cajan (L.) Millsp.] regenerated plants. Legume Genomics and Genetics. 2016; 7(4):1-9.

34. Srivastava J, Pramod K, Raghav. Effect of different gibberellic acid concentration on pigeon pea (cajanus cajan [1.] Millsp.) cv. Manak (h77216) via cotyledonary node explants. International Journal of Advanced Biotechnology and Research. 2014; 5(2):151-6.

35. Franklin G, Jeyachandran R, Ignacimuthu S. Factors affecting regeneration of pigeon pea (Cajanus cajan L. Millsp) from mature embryonal axes. Plant Growth Regulation. 2000; 30(1):31-6. https://doi.org/10.1023/A:1006394402210

36. Nirmala $\mathrm{N}$, Vasavi rama K. Efficient shoot induction and plant regeneration of pigeon pea [Cajanus cajan (L.) millisp.] ICPL 87 variety using leaf petiole explants. International Journal of Applied Biology and Pharmaceutical Technology. 2017; 8(4):30-5.

37. Gaurav Krishna P, Sairam Reddy, Pramod W, Ramteke, Pogiri Rambabu, Sayed S. In vitro regeneration through organogenesis and somatic embryogenesis in pigeon pea [Cajanus cajan (L.) Millsp.] Cv. JKR105. Physiology and Molecular Biology of Plants. 2011; 17(4):375-85. 
PMid: 23573031 PMCid: PMC3550589. https://doi. org/10.1007/s12298-011-0079-1

38. Mehta U, Mohan Ram HY. Regeneration of plantlets from the cotyledons of Cajanus cajan L. Indian Journal of Experimental Biology. 1980; 18:800-2.

39. Padmavathi, Thangella AV, Fakrudin B. In vitro callus induction and regeneration of multiple shoots through callus derived from leaf and epicotyl explants in pigeon pea (Cajanus cajan L.). Legume Research. 2017; 40(5):785-94.

40. Asande LK, Indieka AS, Adero MO, Kiboi S, Amugune NO. In vitro regeneration of pigeon pea using leaf explants. African Crop Science Journal. 2016; 24(2):191-201. https://doi.org/10.4314/acsj.v24i2.7

41. Raghavendra T, Sudhakar P. Pattern of plant regeneration from shoot tip explants of pigeon pea [Cajanus cajan (L.) Millsp.] Var LRG-41. International Journal of Applied Biology and Pharmaceutical Technology. 2014; 5(1):261-6.

42. Majumdar S, Baneerjee S. Efficient shoot regeneration in pigeon pea, Cajanus cajan (L) Millsp. using seedling petioles. Current Science. 2004; 86(1):30-2.

43. Aboshama HMS. Somatic embryogenesis proliferation, maturation and germination in Cajanus cajan. World Journal of Agricultural Sciences. 2011; 7(1):86-95.

44. Krishna G, Reddy SP, Ramtek P, Rambabu P, Sohrab SS. In vitro regeneration through organogenesis and somatic embryogenesis in pigeon pea [Cajanus cajan (L.) Millsp.] Cv. JKR105. Physiology and Molecular Biology of Plants. 2011; 17(4):375-85. PMid:23573031 PMCid: PMC3550589. https://doi.org/10.1007/s12298-011-0079-1

45. Vandana K, Bijaya KS, Manoj Kumar Y, Dinesh Y 2011. Assessment of in vitro Multiple Shoot Bud Induction from Leaf Explants among Eleven Indian Cultivars of pigeon pea [Cajanus cajan (L.) Millsp.]. Indian Streams Research Journal. 2011; 12(4):1-9.

46. Mohamed MF, Read PE, Coyne DP. Plant regeneration in vitro from the embryonic axes of common and tepary beans. Bean Imp Co-op Bull. 1991; 34:149-53.

47. Nagi W, Ignacimuthu S, Becker J. Genetic engineering and regeneration of Phaseolus and Vigna. State the art and new attempts. Journal of Plant Physiology. 1997; 150(6):625-44. https://doi.org/10.1016/S0176-1617(97)80277-5

48. Malik KA, Saxena PK. Somatic embryogenesis and shoot organogenesis from intact seedlings of Phaseolus acutifolius., P. Aureus (L) Wilczek, P. Coccineus and P. Wrightii L. Plant Cell Reports. 1992; 11(3):163-8. PMid: 24213552. https://doi.org/10.1007/BF00232172

49. Singh ND, Sahoo L, Neera BS, Jaiwal PK. The effect of TDZ on organogenesis and somatic embryogenesis in pigeon pea (Cajanus cajan L. Millsp). Plant Science. 2003; 164(3):341-7. https://doi.org/10.1016/S0168-9452(02)00418-1 